\title{
Time and Sequence of Inflorescence Initiation and Development of Brunia albiflora (Pillans)
}

\author{
Caroline J. Poole, Audrey I. Gerber ${ }^{1}$, and Gerard Jacobs ${ }^{2}$ \\ Department of Horticultural Science, University of Stellenbosch, Private Bag \\ X1, Matieland, 7602, South Africa
}

Additional index words. Bruniaceae, Proteaceae, vegetative development, reproductive
development

\begin{abstract}
Brunia albiflora (Pillans) is harvested commercially in South Africa as a cut flower for export to European markets. To compete with European cut flowers high quality and continuity of product during the marketing period are essential. Optimizing the cut-flower potential of $B$. albiflora requires an understanding of the flowering process and selection of clonal material. We present a series of scanning electron micrographs which show three-dimensional images of the developmental stages of the shoot apex during the transition from the vegetative to the reproductive state. In B. albiflora the inflorescence consists of more than 15 individual rotund inflorescences arising from lateral positions on the terminal portion of the shoot. Development of the apical meristem of axillary shoots was studied to determine the time and sequence of inflorescence initiation and development. These observations identified that flower initiation occurs in October, followed by flower development through summer, with anthesis being reached from February to March.
\end{abstract}

Members of the family Proteaceae dominate the South African indigenous cut flower industry. Many indigenous products, however, do not fall into this family and are marketed as 'Cape Greens' of which the Bruniaceae family forms an important part. The four genera of horticultural importance are Brunia, Berzelia, Nebelia, and Staavia. Only 15 of 74 species in these families, however, are harvested commercially (Malan, 1996). Some species have good potential for cultivation, but little is known about their growth and development or cultural requirements.

In Brunia albiflora, flowering shoots arise from axillary buds on the shoot portion remaining after pruning or harvesting. A period of $\approx 24$ months is required from the start of shoot growth until harvest. Shoot growth is continuous, with the most rapid phase occurring during the summer months (Sept. to Mar., Southern Hemisphere) (Poole, 1999). The "flower" is a compound inflorescence, consisting of many individual rotund inflorescences each $\approx 1.5 \mathrm{~cm}$ wide. On a single shoot, individual inflorescences comprising the compound inflorescence reach anthesis about synchronously.

Submitted for publication 30 Oct. 2000. Accepted for publication 30 July 2001. This paper is a portion of a MS. thesis submitted by C.J.P. to the Univ. of Stellenbosch. The work was done under the guidance of G. Jacobs and was completed for graduation in Dec. 1999. The thesis was evaluated and accepted by KarenI. Theron, Dawid Saayman, and Gerhard Malan. ${ }^{1}$ To whom reprint requests should be addressed. Current address: Dept. of Natural Resources and Environment, NRE Ovens, P.O. Box 235, Myrtleford, VIC 3737, Australia. E-mail address: Audrey.Gerber@nre.vic.gov.au

${ }^{2}$ Professor.
The objective of this study was to determine the time of inflorescence initiation of $B$. albiflora, and to qualify the progression of inflorescence differentiation and development. A series of scanning electron micrographs is presented, showing the development of the apical meristem of the primary shoot, relative to axillary shoots, from the vegetative phase to after anthesis.

\section{Material and Methods}

Plants of B. albiflora, grown from cuttings, originating from seedling blocks (therefore, a mixture of clones), were established in 1995 on a commercial flower farm in the Elgin area of the Western Cape, South Africa (lat. $19^{\circ} 02^{\prime} \mathrm{E}$; long. $34^{\circ} 08^{\prime} \mathrm{S}$ ). Elgin is characterized by a Mediterranean climate of cold, wet winters and warm, dry summers. Plant density was 13,000 plants/ha. Plants were drip-irrigated to supplement rainfall and fertigated from August to March to replace nutrients removed by harvesting (Claassens, 1985).

Terminal and axillary shoot apices were taken at weekly intervals from 8 Apr. 1997 to 26 Feb. 1998 from shoots which had not flowered in 1997. Samples were prepared for electron microscopy and photographed, as described for Protea (Gerber et al., 2001).

\section{Results and Discussion}

Vegetative growth of B. albiflora occurred from the start of observations until the end of May 1997. Elongation of the primary shoot was accompanied by growth of sylleptic side shoots arising from axillary buds in leaf axils on the primary shoot (Fig. 1). These sylleptic side shoots developed at irregular intervals.
The apical meristem of the primary shoot and sylleptic side shoots were both vegetative in April and May, although the apical meristem of the primary shoot was slightly larger than that of sylleptic side shoots. Axillary buds were visible in leaf axils of the terminal portion of the primary shoot in May and none were visible on sylleptic side shoots.

When growth of the primary shoot terminated in late summer, many upper axillary buds developed proleptically and elongated. The primary shoot apex remained vegetative and axillary shoots elongated past it, forming inflorescences in terminal positions (Fig. 2).

As a result of these observations, reproductive development of B. albiflora was divided arbitrarily into four macroscopically visible phases, described in Table 1, and depicted in Fig. 3. Phase 1 (Fig. 3A) was clearly visible in August, although the precise time at which each stage was visible varied between plants because the population was a mixture of clones. Phase II (Fig. 3B) continued from September to December, accompanied by inflorescence enlargement. Elongation of proleptic side shoots subtending inflorescences was complete in January, and the final stages of inflorescence enlargement occurred (Phase III). Brunia albiflora is harvested before anthesis, either during Phase II while individual inflorescences are small and green (Fig. 3B), or at the end of Phase III when inflorescences are large and silvery white (Fig. 3C) (Rugge, 1997). The final macroscopically visible phase was apparent in February and March, when individual florets reached anthesis (Fig. 3D). At anthesis, shoots subtending inflorescences were $4-5 \mathrm{~cm}$ long, with all inflorescences held on the same plane (Fig. 2).

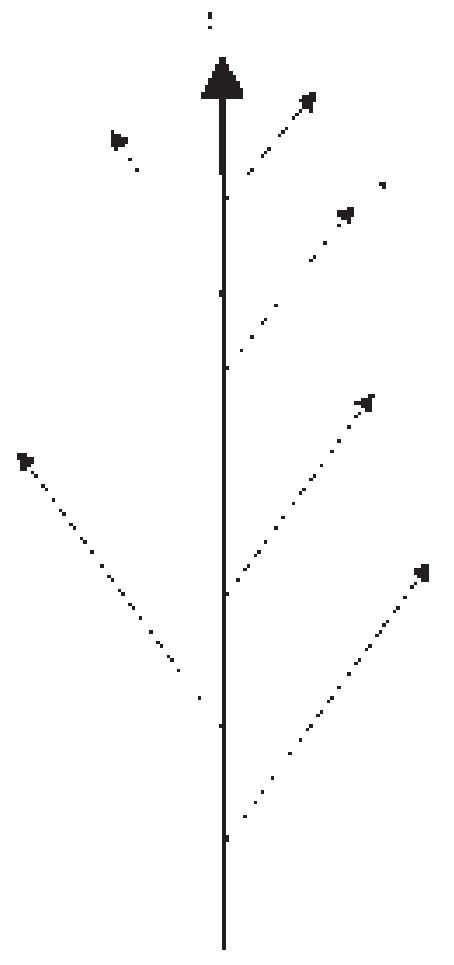

Fig. 1. Schematic representation of vegetative shoot of Brunia albiflora, showing apical meristems of (1) primary shoot and (2) sylleptic side shoots. 
Microscopic inflorescence development from the vegetative to reproductive state of the apical meristem of proleptic axillary shoots for B. albiflora occurred in the sequence summarized in Table 2. Scanning electron micrographs (Figs. 4 and 5) illustrate the transition from vegetative to reproductive phase of apical meristems of proleptic axillary shoots, followed by the development of florets.

Fig. 4A shows the primary shoot before the loss of apical dominance. Stage V1, as shown in Fig. 4B, was the first evidence of commitment to reproductive development and was observed microscopically as a rapid development of axillary buds in June. Apical meristems of proleptic axillary shoots changed rapidly from July to September. Size increased, denoting stage V2. By September, apical meristems of proleptic axillary shoots were the same size as the apical meristems of the primary shoot. Not all axillary buds underwent enlargement and elongation.

At the end of October stage R1 occurred, evidenced by a flattening of the meristem, as seen in Leucospermum (Malan et al., 1994) and Protea (Gerber et al., 2001). In November, floret primordia were apparent on en-
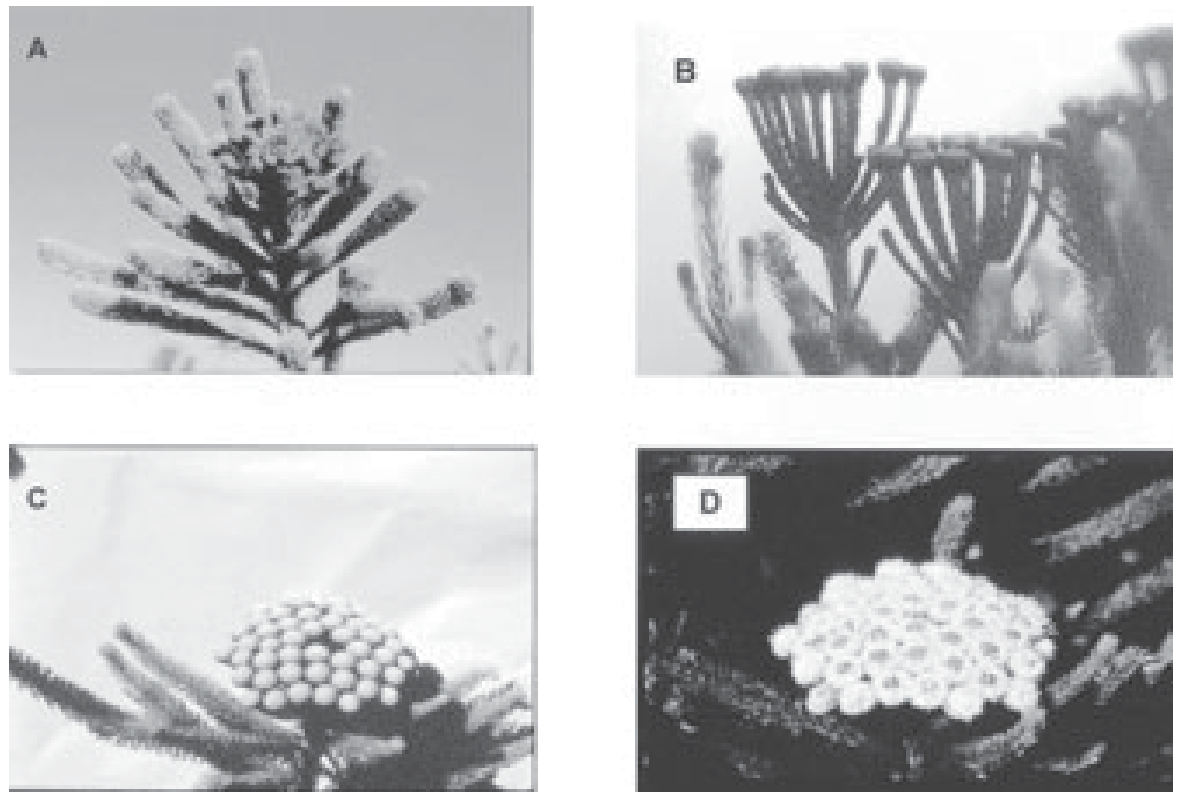

Fig. 3. Reproductive development of Brunia albiflora, corresponding to the 4 macroscopically visible phases described in Table 1.

Table 2. Classification of stages of inflorescence development of Brunia albiflora.

\begin{tabular}{ll}
\hline \hline Stage & \multicolumn{1}{c}{ Description } \\
\hline V1 & $\begin{array}{l}\text { Loss of apical dominance, enlargement } \\
\text { of axillary buds }\end{array}$ \\
V2 & $\begin{array}{c}\text { Elongation of axillary shoots, with apical } \\
\text { meristem dome shaped }\end{array}$ \\
R1 & $\begin{array}{c}\text { Dome-shaped apical meristem of axillary } \\
\text { shoot widened and flattened }\end{array}$ \\
R2 & $\begin{array}{l}\text { Initiation of bract primordia } \\
\text { R3 }\end{array}$ \\
Initiation of floral primordia \\
P & $\begin{array}{l}\text { Perianth initials formed (5) } \\
\text { A }\end{array}$ \\
Androecium initials formed (5) \\
Aa & Gynoecium initials formed \\
Go & Anthers visible \\
F & Anule visible \\
\hline
\end{tabular}

larged, flattened meristems, indicating the start of stage R3. Floret primordia were subtended by villous floral bracts (Fig. 5A). Initiation of florets began on the outer edge of the receptacle and continued acropetally, with the peripheral primordia developing earliest. This pattern is consistent with floret development in Banksia (Fuss and Sedgley, 1990) and Protea (Gerber et al., 2001).

Stage $\mathrm{P}$, during which perianth initials formed, occurred in December (Fig. 5B). Five perianth initials formed in a single whorl. The inner whorl shows the beginning of stage A during which androecium initials are formed. The shape of the inflorescence and the arrangement of the florets on the meristem is shown in Fig. 5C. After androecium formation, cells rose up to form a meristematic ring, which produced the carpel primordia (Fig. 5D). The ovary of B. albiflora is bilocular (Fig. 5E). A single floret has linear elliptic petals which taper to the base, and villous bracts reaching to the middle of the petals (Fig. 5F).

The set of scanning electron micrographs of the morphological development of apical meristems of axillary shoots of $B$. albiflora

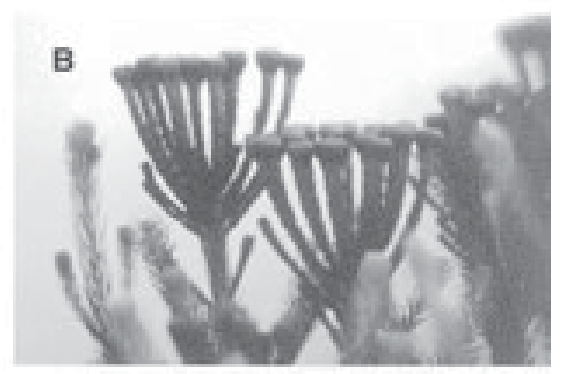

Table 1 . Phases of macroscopically visible repro-

\begin{tabular}{lc}
\hline Phase & Description \\
\hline I & $\begin{array}{c}\text { Increase in primary shoot tip } \\
\text { complexity, brought about by rapid } \\
\text { proleptic development of axillary buds } \\
\text { Elongation of axillary shoots subtending } \\
\text { Individual inflorescences }\end{array}$ \\
III & $\begin{array}{c}\text { Enlargement of individual inflorescences } \\
\text { to final size }\end{array}$ \\
IV & Floret anthesis \\
\hline
\end{tabular}
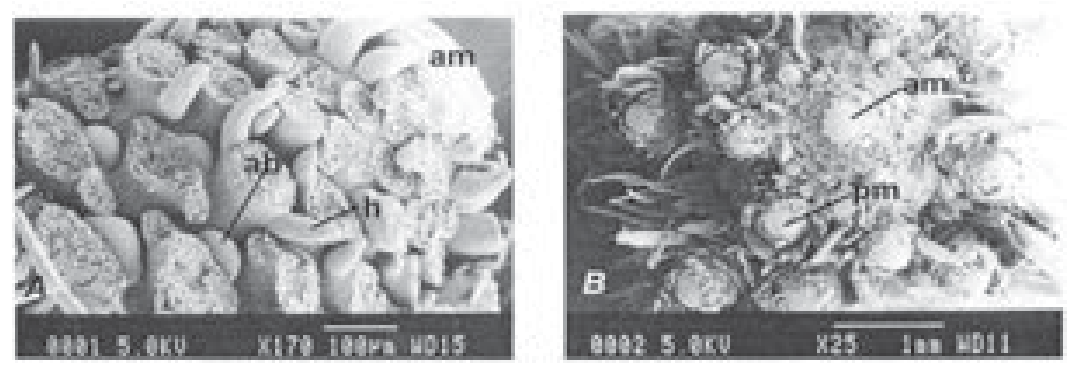

Fig. 4. Scanning electron micrographs of the primary shoot apex of Brunia albiflora in the vegetative stage. (A) apical meristem (am) and axillary buds (ab) in leaf axils with developing hairs (h) (20 May 1997). (B) terminal apical meristem (am) and apical meristem of proleptic side shoots (pm) (13 Aug. 1997). 


\section{Breeding, Cultivars, Rootstocks, \& Germplasm Resources}
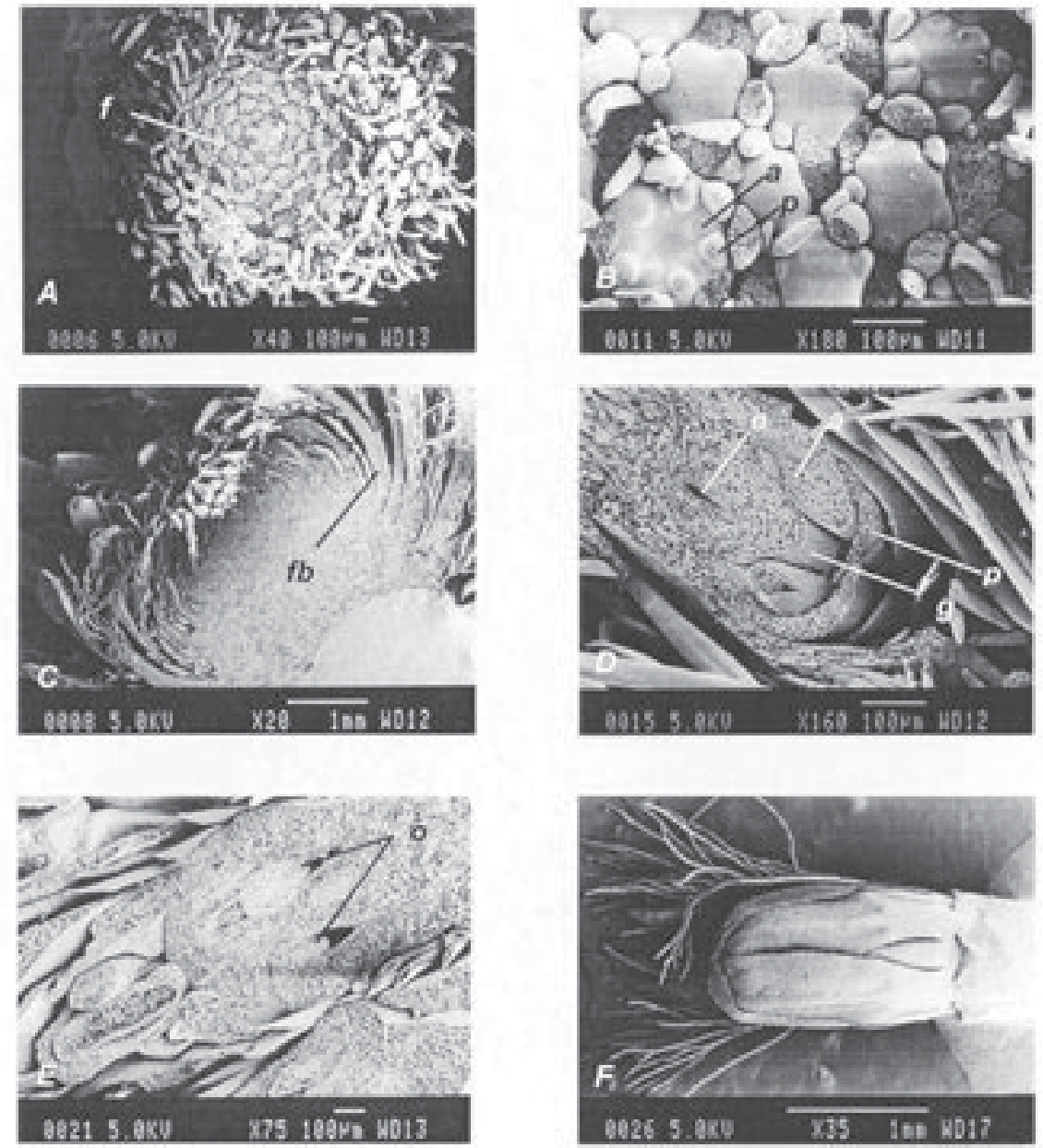

Fig. 5. Scanning electron micrographs of the reproductive stages of Brunia albiflora. (A) individual floret primordia (f) on the apex of proleptic side shoots (stage R3, 4 Nov. 1997). (B) initiation of perianth initials (p) in a whorl of 5 (stage P), and the start of androecium initials (a), also in a single whorl of 5 (2 Dec. 1997). (C) inflorescence cross section, showing the position of florets in axils of villous floral bracts (fb). (D) Single floret with ovary developing (o) (30 Dec. 1997). Perianth (p), androecium (a), and gynoecium (g) visible. (E) bilocular ovary (o) of single floret (9 Feb. 1998). (F) single floret prior to anthesis (26 Feb. 1998). provides the basis for describing floral initiation, differentiation and growth. Floral initiation was indicated by the widening and flattening of apical meristems of side shoots, and occurred in October. Although the first stages of flower initiation were apparent in October, the increase in tip complexity due to proleptic axillary shoot growth, which is a prerequisite event for flowering, occurred in August, indicating that inductive conditions prevailed some months prior to flower initiation. This is similar to the pattern of induction and initiation observed in Protea (Gerber et al., 2002), and suggests that low temperatures and short daylength may play an inductive role in flowering of B. albiflora.

\section{Literature Cited}

Claasens, A.S. 1986. Some aspects of the nutrition of proteas. Acta Hort. 185:171-179.

Fuss, A.M. and M. Sedgley. 1990. Floral initiation and development in relation to the time of flowering of Banksia coccinea R.Br. and B. menziesii R.Br. (Proteaceae). Austral. J. Bot. 38:487-500.

Gerber, A.I., K.I. Theron, and G. Jacobs. 2001. Synchrony of inflorescence initiation and shoot growth of selected Protea cultivars. J. Amer. Soc. Hort. Sci. 126:182-187.

Gerber, A.I., K.I. Theron, and G. Jacobs. 2002. Defoliation alters spring growth flush characteristics and inhibits flowering in Protea cv. Carnival. Scientia Hort. (In Press.)

Malan, D.G. 1996. The fynbos ornamental industry: 1993-1995. Published by SAPPEX, Bot River, South Africa.

Malan, D.G., J.G.M. Cutting, and G. Jacobs. 1994. Correlative inhibition of inflorescence development in Leucospermum 'Red Sunset'. J. S. Afr. Soc. Hort. Sci. 4(1):26-31.

Pillans, N.A. 1947. A revision of Bruniaceae. J. S. Afr. Bot. 13:121-206.

Poole, C.J. 1999. Growth and nutrition of Bruniaceae. MSc. Thesis, Univ. Stellenbosch.

Rugge, B.A. 1997. Cape Greens, p. 3.1-3.15. In: J.H Coetzee (ed.). Protea cultivation. ARC: Fynbos. Private Bag X1, Elsenburg 7607, South Africa. 